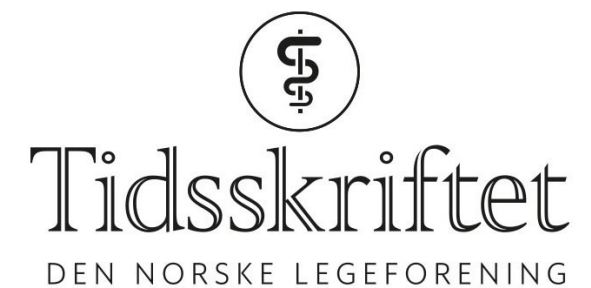

DEN NORSKE LEGEFORENING

\title{
Skadeforebygging gir bedre helse
}

LEDER

\section{$B \varnothing R G E \quad Y T T E R S T A D$}

E-post: boergey@online.no

Børge Ytterstad er professor emeritus ved Universitetet i Troms $\emptyset$ - Norges arktiske universitet, Campus Harstad.

Forfatter har fylt ut ICMJE-skjemaet og oppgir ingen interessekonflikter.

Skadeepidemiologisk forskning og forebygging av skader er avhengig av gode data om hvor, når og hvordan skader skjer.

Ulykker er den viktigste årsaken til dødsfall for personer under 45 år (1). I tillegg forårsaker ulykker et stort antall personskader som ikke medfører $\mathrm{d} ø \mathrm{~d}$, men som kan ha alvorlige konsekvenser både for den enkelte og for samfunnet. Et anslag fra 2011 tilsier at et ulykkesdødsfall koster ca. 30 millioner kroner, og at behandlingen av hardt og lett skadde koster hhv. 11 millioner kroner og vel 600 ooo kroner (2). Skader og dødsfall etter ulykker har et stort forebyggingspotensial, og en reduksjon av ulykker vil kunne gi en solid helsegevinst i befolkningen (1).

Mens forebygging av kreft og hjerte- og karsykdommer krever tiår for robust evaluering, kan effekten av god skadeforebygging dokumenteres etter få år. I Harstad Injury Prevention Study ble det dokumentert reduksjoner i skaderater gjennom ti år, skaderater for brannskader hos barn, fallfrakturer hos eldre og trafikkulykker (3). Lokale data fra det nasjonale skaderegisteret, administrert av Folkehelseinstituttet, gjorde det mulig å gjøre gode analyser, målrettede intervensjoner og robuste evalueringer. Harstad ble første kommune i Norge og nr. 11 i verden som ble sertifisert av WHO som et trygt lokalsamfunn (4). Dessverre ble en stilling for kvalitetssikring av skaderegistrering i Harstad inndratt i 2016 med en uforståelig begrunnelse om at omstillingstiltak var nødvendig. Konsekvensen av dette tiltaket er nedlegging av fremtidig skadeepidemiologisk forskning ved Universitetssykehuset Nord-Norge, Harstad, som har registrert data i perioden 1985-2015 (5).

Det nasjonale registeret ble nedlagt i 1992. Ni år senere ble det erstattet av et obligatorisk nedskalert nasjonalt skaderegister, et såkalt Felles Minimum Data Sett (FMDS). Dessverre ble viktige variabler tatt ut. F.eks. er verken snøscooter eller vannscooter oppført under fremkomstmiddel. I Harstad-registeret er det lett å finne forekomst av personskader ved bruk av snøscooter ved et par tastetrykk. Registeret fra 2001 har betydelige mangler og er lite egnet for analyser av det nasjonale skadepanoramaet eller for forebygging av skader i Norge utenom Oslo. Oslo universitetssykehus har bidratt med over halvparten av alle registeringer til tross for at befolkningen i Oslo bare utgjør $12 \%$ av Norges befolkning. Fra de øvrige sykehusene i landet er registreringene mangelfulle til tross for et lovpålagt ansvar (6).

I en studie av dødsfall og personskader ved bruk av snøscooter og ATV (All Terrain Vehicles) 
i Nord-Norge, som nå publiseres i Tidsskriftet, etterspør forfatterne offisiell statistikk om skader ved bruk av slike fremkomstmidler (7). I mangel av slike data måtte de lete i politiets arkiver, sykehusjournaler, traumeregistre og på internett. Her er det gjort et beundringsverdig og tidkrevende arbeid. Resultatene viste at syv personer ble drept under kjøring med snøscooter og ingen under kjøring med ATV i 2013-14. Antall personskader under kjøring med snøscooter og ATV var hhv. 74 og 13. Studien blir publisert på et gunstig tidspunkt og kan være en referansestudie for senere studier. Norske kommuner fikk i mai 2015 selvstyre over reguleringen av ferdsel med snøscooter, noe som kan endre bruken og dermed skadepanoramaet.

«Vi bruker for mye penger av helsebudsjettet på behandling og for lite på forebyggende tiltak», uttalte stortingspolitiker Kjersti Toppe i 2013 (8). Slik er det dessverre fortsatt. Mer satsing på nasjonal registrering av skader ville vært et skritt i riktig retning. På det lokale plan bør sykehusene gis anledning til å benytte skadedata som de selv registrerer. Hvert sykehus må tilføres midler til personell som kan ha et overordet ansvar for å kvalitetssikre skaderegistrering. Antallet registrerte variabler i skaderegistrene bør økes. Helsedirektoratet og sykehusene har en jobb å gjøre.

\section{LITTERATUR:}

1. Myklestad I, Alver K, Madsen C et al. Skadebildet i Norge: Hovedvekt på personskader i sentrale registre. Rapport 2014:2. Oslo: Folkehelseinstitutt, 2014.

https://www.fhi.no/globalassets/dokumenterfiler/rapporter/2014/skadebildet-i-norge-hovedvekt-pa-pe rsonskader-i-sentrale-registre-pdf.pdf(19.3.2019).

2. Transportøkonomisk institutt. Et spart liv i trafikken verdsatt til 30 millioner kroner. https://www.toi.no/forsiden/et-spart-liv-i-trafikken-verdsatt-til-30-millioner-kroner-article299o8-4.htm l(19.3.2019).

3. Ytterstad B. Harstad Injury Prevention Study. Doktorgradsavhandling. Tromsø: Institutt for samfunnsmedisin, Universitetet i Tromsø, 1995.

4. Ytterstad B. Ulykker og skader. I: Klepp KI, Aarø LE, red. Ungdom, livstil og helsefremmende arbeid. Oslo: Gyldendal Akademisk, 2017.

5. Guldvog B, Thorgersen A, Ueland Ø. Ulykker, vold og selvpåført skade. Rapport nr. 1/92. Oslo: Folkehelseinstituttet, 1992.

6. Helsedirektoratet. Personskadedata. https://helsedirektoratet.no/publikasjoner/personskadedata (9.1.2019)

7. Rønning TH, Grov EK, Wisborg T. Dødsfall og personskader ved bruk av ATV og snøscooter i NordNorge i 2013-14. Tidsskr Nor Legeforen 2019; 139. doi: 10.4045/tidsskr.18.o966. [CrossRef]

8. Toppe K. Mer forebygging - mindre reparasjon. Tidsskr Nor Legeforen 2013; 133: 1566. [CrossRef]

Publisert: 8. april 2019. Tidsskr Nor Legeforen. DOI: 10.4045/tidsskr.19.0231

(C) Tidsskrift for Den norske legeforening 2020. Lastet ned fra tidsskriftet.no 